\title{
The Solution to Science's Replication Crisis
}

\author{
Bruce Knuteson*
}

\begin{abstract}
The solution to science's replication crisis is a new ecosystem in which scientists sell what they learn from their research. In each pairwise transaction, the information seller makes (loses) money if he turns out to be correct (incorrect). Responsibility for the determination of correctness is delegated, with appropriate incentives, to the information purchaser. Each transaction is brokered by a central exchange, which holds money from the anonymous information buyer and anonymous information seller in escrow, and which enforces a set of incentives facilitating the transfer of useful, bluntly honest information from the seller to the buyer. This new ecosystem, capitalist science, directly addresses socialist science's replication crisis by explicitly rewarding accuracy and penalizing inaccuracy.

The problematic incentives within socialist science that have led to socialist science's replication crisis are too embedded to remove. Those seeking accurate knowledge to inform important, high stakes decisions will gradually start to rely on capitalist science, which penalizes the selling of information that turns out to be wrong. Researchers with genuinely valuable information will choose to sell it rather than publish it away for free. The most useful, interesting, and accurate information will therefore gradually move from the ecosystem of socialist science to the ecosystem of capitalist science, where it is properly valued.

Capitalist science is the solution to socialist science's replication crisis.
\end{abstract}

\section{SOCIALIST SCIENCE}

Drug company Q reads a scholarly article in a distinguished journal authored by academic A. Motivated in significant part by A's findings, Q starts a new research effort in this seemingly promising direction.

One year and one million dollars later, Q realizes A's findings are basically wrong [1-15].

Variants of this story may be invoked by a convenient buzz phrase: science's "replication crisis," "replicability crisis," or "reproducibility crisis." Q is not always a drug company. A is usually an academic.

Q, the sucker in this story, realizes he is continually getting shafted [16-24]. Systematic attempts to repeat many published studies fail [25-30], spreading awareness to the masses and stoking discontent. Debates erupt over the scale of the problem [31-38]. Some hope extermination of psychology departments will be sufficient [39-46]. Others work to re(de)fine the notion of "replication" [4749]. Incremental improvements to the current system are proposed [50-90] [163]. Most are never enacted [91]. The rest have limited impact [92-104].

The incentive structures contributing to the replication crisis are observed to be deeply entrenched features of the ecosystem within which science is done [105-136] and subsequently applied [137-148]. This ecosystem comprises institutions (including funding agencies, industry, universities, and academic journals), culture, accepted practice (including procedures by which grant money is awarded, articles published, promotions granted, and accolades bestowed), and the bureaucracy required to support all of these. The ecosystem is complex, multifaceted,

\footnotetext{
*URL: http://bruceknuteson. com; Electronic address:
} knuteson@kn-x.com and not easily changed. The incentive structures contributing to the replication crisis are, similarly, not easily changed. A timely solution to the replication crisis probably requires a new ecosystem.

For convenience, we refer to the current ecosystem [149] - funded by taxpayers, with published results available to all citizens - as socialist science [164] [165].

\section{CAPITALIST SCIENCE}

Perhaps we can construct a different ecosystem.

Lacking imagination, we look to see what other professions do. Many professions exhibit a very interesting behavior. There occur pairwise transactions, in which one party sells something of value to another party. One party (A) gives something of value to some other party (Q). In return, Q gives A something called money.

Perhaps our academic (A) can sell what he learns to those (Q) who find A's information valuable. Many deep pocketed industries, including the pharmaceutical industry, make high stakes decisions motivated by academic research. A should have little difficulty finding customers Q.

To incentivize accuracy, we need some sort of transaction that causes A to lose money if he turns out to be wrong. We therefore need transactions for which the (in)accuracy of A's information can eventually be objectively determined, and we need a reliable, low-cost procedure for making that determination.

Suppose Q has a specific question and is willing to pay for a useful answer. Q can ensure the usefulness of any answer he receives by specifying, explicitly or categorically, the set of allowed possible answers. A third party (X) brokers the transaction, holds money from $\mathrm{Q}$ and $\mathrm{A}$ in escrow, and acts as arbiter. If A provides an answer outside Q's set of allowed possible answers, A loses 
money.

In many cases of practical interest, $\mathrm{Q}$ can be tasked with determining the accuracy of A's answer. If $\mathrm{Q}$ wants to know what chemical matter binds to a particular target and A answers with a specific molecule, Q will eventually know whether A's answer was right or wrong, and $\mathrm{Q}$ can provide evidence to this effect to arbiter X. X collects a deposit from $\mathrm{Q}$ at the beginning of the transaction, and $\mathrm{X}$ returns this deposit to $\mathrm{Q}$ when $\mathrm{Q}$ provides sufficient evidence by a previously agreed upon date. Q pays the same amount whether A's answer turns out to be right or wrong. X's fee for brokering the transaction is independent of whether A's answer turns out to be right or wrong and whether or not $\mathrm{Q}$ provides evidence $\mathrm{X}$ considers sufficient. A has an explicit monetary incentive to be accurate and an explicit monetary disincentive to provide information unless he is pretty sure he is correct. Q has an explicit monetary incentive to ask a question that will be directly useful to him, and for which he can eventually determine, with reasonable proof, the accuracy of whatever answer A provides. X, as an ongoing business interest, has a clear monetary incentive to thoughtfully serve its role as a reasonable and objective adjudicator of the evidence $\mathrm{Q}$ provides. Q, A, and X all have an interest in ensuring Q's question is carefully specified to avoid subsequent ambiguities as to A's correctness. This transaction protocol enforces a set of incentives facilitating paid, arm's length transfer of useful, bluntly honest information from A to Q.

Using this transaction protocol, introduced for the first time in Ref. [150] and implemented at Ref. [166], scientists can sell what they learn from their research.

For convenience, we refer to this new ecosystem as capitalist science [167] [168] [169].

In capitalist science, A makes money only if he turns out to be correct. A loses money if he turns out to be wrong. Every transaction includes a monetary incentive for Q to determine the accuracy of A's answer and to back this determination with evidence deemed sufficient by an objective third party $(\mathrm{X})$. These features directly address socialist science's reproducibility crisis. These incentives, present in capitalist science, explicitly and directly reward accuracy and penalize inaccuracy. The absence of such explicit and direct incentives in socialist science is the reason socialist science is suffering a reproducibility crisis.

Capitalist science is the solution to socialist science's reproducibility crisis.

\section{SUMMARY}

Now that the solution to socialist science's reproducibility crisis has been found, we can roll up our sleeves ... sit back, relax, and let events unfold.
Socialist science will continue much as it has, producing results of similar quality. Serious, thoughtful, and impassioned attempts will be made to save it. Some of these may appear to work for a while, but ultimately they will fail. The reproducibility crisis has been stewing for decades [151-161]. The relevant malincentives are too firmly embedded in its large and unwieldy ecosystem for socialist science to produce a meaningful solution from within.

The key to change is $\mathrm{Q}$, the socialist science sucker from Section I. Q is smart. Q is a socialist science sucker only because socialist science fails to sufficiently discourage the publication of inaccurate information by failing to hold A sufficiently accountable for being wrong. Q is a socialist science sucker only because Q has had no other option.

Q now has another option. Before launching a one year, one million dollar research project motivated by a result produced by socialist science, Q can spend ten days and ten thousand dollars on a few questions to check it out. Before investing ten million dollars on a new materials science innovation, venture capitalists can anonymously conduct due diligence with a convenience and at a depth hitherto unimaginable. Relying on free information of questionable accuracy produced by socialist science can be very costly. Q is smart; Q is accustomed to paying for things of value; and Q's stakes are high.

Over time, Q increasingly relies on information obtained from capitalist science, where A has skin in the game. When A has truly valuable information, he finds himself more interested in selling it than publishing it. For less robust results, A is more inclined to publish, avoiding the harsh penalty imposed by capitalist science for providing information that turns out to be wrong. Over time, useful, robust information slowly migrates to capitalist science, where it is appropriately valued. Socialist science continues to publish the results $\mathrm{A}$ is willing to give away for free.

The forces in capitalist science's favor are so strong that socialist science should be allowed to fade into irrelevance in its natural course [170]. Socialist science has been a remarkable institution. The knowledge it has provided has been extraordinary in power and in scope. Its use of an incentive structure spurned by the most developed of today's modern economies only makes its achievements all the more impressive.

We fully hope and expect socialist science will linger among us for many years. At some deep level, the purpose and goals of socialist science are fundamentally different from those of capitalist science. Capitalist science is designed to facilitate useful, accurate information transfer, and to provide A with a strong incentive to learn information some Q will find valuable. Socialist science, in contrast, is not. 
[1] Begley CG, Ellis LM. Drug development: raise standards for preclinical cancer research. Nature. 2012;483(7391):531-533.

[2] Prinz F, Schlange T, Asadullah K. Believe it or not: how much can we rely on published data on potential drug targets? Nature Reviews Drug Discovery. 2011;10(9):712-712.

[3] Freedman LP, Cockburn IM, Simcoe TS. The economics of reproducibility in preclinical research. PLoS Biol. 2015;13(6):e1002165.

[4] Chalmers I, Glasziou P. Avoidable waste in the production and reporting of research evidence. Obstetrics \& Gynecology. 2009;114(6):1341-1345.

[5] Scott S, Kranz JE, Cole J, Lincecum JM, Thompson K, Kelly N, et al. Design, power, and interpretation of studies in the standard murine model of ALS. Amyotrophic Lateral Sclerosis. 2008;9(1):4-15.

[6] Begley CG. An unappreciated challenge to oncology drug discovery: pitfalls in preclinical research. Am Soc Clin Oncol Educ Book. 2013;33:466-468.

[7] Steckler T. Preclinical data reproducibility for R\&D - the challenge for neuroscience. Psychopharmacology. 2015;232(2):317-320.

[8] De Los Angeles A, Ferrari F, Fujiwara Y, Mathieu R, Lee S, Lee S, et al. Failure to replicate the STAP cell phenomenon. Nature. 2015;525(7570):E6-E9.

[9] Kola I, Landis J. Can the pharmaceutical industry reduce attrition rates? Nature Reviews Drug Discovery. 2004;3(8):711-716.

[10] Macleod MR, Michie S, Roberts I, Dirnagl U, Chalmers I, Ioannidis JP, et al. Biomedical research: increasing value, reducing waste. The Lancet. 2014;383(9912):101104.

[11] Kyzas PA, Denaxa-Kyza D, Ioannidis JP. Almost all articles on cancer prognostic markers report statistically significant results. European Journal of Cancer. 2007;43(17):2559-2579.

[12] Hirst JA, Howick J, Aronson JK, Roberts N, Perera R, Koshiaris C, et al. The need for randomization in animal trials: an overview of systematic reviews. PLoS ONE. 2014;9(6):e98856.

[13] Hyman SE. Revolution stalled. Science Translational Medicine. 2012;4(155):155cm11.

[14] Miller G. Is pharma running out of brainy ideas? Science. 2010;329(5991):502-504.

[15] Schoenfeld JD, Ioannidis JP. Is everything we eat associated with cancer? A systematic cookbook review. The American Journal of Clinical Nutrition. 2013;97(1):127134.

[16] Ioannidis JP. Why most published research findings are false. PLoS Med. 2005;2(8):e124.

[17] Ioannidis J, Doucouliagos C. What's to know about the credibility of empirical economics? Journal of Economic Surveys. 2013;27(5):997-1004.

[18] Pankevich DE, Altevogt BM, Dunlop J, Gage FH, Hyman SE. Improving and accelerating drug development for nervous system disorders. Neuron. 2014;84(3):546553.

[19] Lowenstein PR, Castro MG. Uncertainty in the translation of preclinical experiments to clinical trials. Why do most phase III clinical trials fail? Current Gene
Therapy. 2009;9(5):368-374.

[20] Henderson VC, Kimmelman J, Fergusson D, Grimshaw JM, Hackam DG. Threats to validity in the design and conduct of preclinical efficacy studies: a systematic review of guidelines for in vivo animal experiments. PLoS Med. 2013;10(7):e1001489.

[21] Dirnagl U, Fisher M. International, multicenter randomized preclinical trials in translational stroke research: it's time to act. Journal of Cerebral Blood Flow \& Metabolism. 2012;32(6):933-935.

[22] Dirnagl U, Macleod MR. Stroke research at a road block: the streets from adversity should be paved with meta-analysis and good laboratory practice. British Journal of Pharmacology. 2009;157(7):1154-1156.

[23] Dirnagl U. Bench to bedside: the quest for quality in experimental stroke research. Journal of Cerebral Blood Flow \& Metabolism. 2006;26(12):1465-1478.

[24] Rosenblatt M. An incentive-based approach for improving data reproducibility. Science Translational Medicine. 2016;8(336):336ed5.

[25] Mobley A, Linder SK, Braeuer R, Ellis LM, Zwelling L. A survey on data reproducibility in cancer research provides insights into our limited ability to translate findings from the laboratory to the clinic. PLoS ONE. 2013;8(5):e63221.

[26] Open Science Collaboration, et al. Estimating the reproducibility of psychological science. Science. 2015;349(6251):aac4716.

[27] Ioannidis JP. Contradicted and initially stronger effects in highly cited clinical research. JAMA. $2005 ; 294(2): 218-228$.

[28] Ioannidis JP. Non-replication and inconsistency in the genome-wide association setting. Human Heredity. 2007;64(4):203-213.

[29] Steward O, Popovich PG, Dietrich WD, Kleitman N. Replication and reproducibility in spinal cord injury research. Experimental Neurology. 2012;233(2):597-605.

[30] Chang AC, Li P. Is economics research replicable? Sixty published papers from thirteen journals say "usually not". 2015;doi:10.2139/ssrn.2669564.

[31] Maxwell SE, Lau MY, Howard GS. Is psychology suffering from a replication crisis? What does "failure to replicate" really mean? American Psychologist. 2015;70(6):487.

[32] Anderson CJ, Bahník Š, Barnett-Cowan M, Bosco FA, Chandler J, Chartier CR, et al. Response to comment on "Estimating the reproducibility of psychological science". Science. 2016;351(6277):1037-1037.

[33] Stroebe W, Strack F. The alleged crisis and the illusion of exact replication. Perspectives on Psychological Science. 2014;9(1):59-71.

[34] Klein RA, Ratliff KA, Vianello M, Adams Jr RB, Bahník Š, Bernstein MJ, et al. Investigating variation in replicability. Social Psychology. 2014;45(3):142-152.

[35] Pashler H, Harris CR. Is the replicability crisis overblown? Three arguments examined. Perspectives on Psychological Science. 2012;7(6):531-536.

[36] Camerer CF, Dreber A, Forsell E, Ho TH, Huber J, Johannesson M, et al. Evaluating replicability of laboratory experiments in economics. Science. 2016;351(6280):1433-1436. 
[37] Etz A, Vandekerckhove J. A Bayesian perspective on the reproducibility project: psychology. PLoS ONE. 2016;11(2):e0149794.

[38] Michalek AM, Hutson AD, Wicher CP, Trump DL. The costs and underappreciated consequences of research misconduct: a case study. PLoS Med. 2010;7(8):e1000318.

[39] Fanelli D. "Positive" results increase down the hierarchy of the sciences. PLoS ONE. 2010;5(4):e10068.

[40] Lilienfeld SO. Public skepticism of psychology: why many people perceive the study of human behavior as unscientific. American Psychologist. 2012;67(2):111.

[41] Cesario J. Priming, replication, and the hardest science. Perspectives on Psychological Science. 2014;9(1):40-48.

[42] Pashler H, Wagenmakers EJ. Editors' introduction to the special section on replicability in psychological science: a crisis of confidence? Perspectives on Psychological Science. 2012;7(6):528-530.

[43] Bakker M, van Dijk A, Wicherts JM. The rules of the game called psychological science. Perspectives on Psychological Science. 2012;7(6):543-554.

[44] Bones AK. We knew the future all along: scientific hypothesizing is much more accurate than other forms of precognition - a satire in one part. Perspectives on Psychological Science. 2012;7(3):307-309.

[45] Wagenmakers EJ, Wetzels R, Borsboom D, van der Maas HL. Why psychologists must change the way they analyze their data: the case of psi: comment on Bem (2011). Journal of Personality and Social Psychology. 2011;100(3):426-432.

[46] Ferguson CJ. "Everybody knows psychology is not a real science": public perceptions of psychology and how we can improve our relationship with policymakers, the scientific community, and the general public. American Psychologist. 2015;70(6):527.

[47] Goodman SN, Fanelli D, Ioannidis JP. What does research reproducibility mean? Science Translational Medicine. 2016;8(341):341ps12.

[48] Brandt MJ, Ijzerman H, Dijksterhuis A, Farach FJ, Geller J, Giner-Sorolla R, et al. The replication recipe: what makes for a convincing replication? Journal of Experimental Social Psychology. 2014;50:217-224.

[49] Clemens MA. The meaning of failed replications: a review and proposal. Journal of Economic Surveys. 2015; doi:10.1111/joes.12139.

[50] Ioannidis JP. How to make more published research true. PLoS Med. 2014;11(10):e1001747.

[51] Collins FS, Tabak LA. NIH plans to enhance reproducibility. Nature. 2014;505(7485):612.

[52] Vesterinen HM, Sena ES, Williams A, Chandran S, Macleod MR, et al. Improving the translational hit of experimental treatments in multiple sclerosis. Multiple Sclerosis. 2010;16(9):1044-1055.

[53] Asendorpf JB, Conner M, De Fruyt F, De Houwer J, Denissen JJ, Fiedler K, et al. Recommendations for increasing replicability in psychology. European Journal of Personality. 2013;27(2):108-119.

[54] Nosek BA, Alter G, Banks G, Borsboom D, Bowman S, Breckler S, et al. Promoting an open research culture. Science. 2015;348(6242):1422-1425.

[55] Cumming G. The new statistics: why and how. Psychological Science. 2014;25(1):7-29.

[56] Iqbal SA, Wallach JD, Khoury MJ, Schully SD, Ioannidis JP. Reproducible research practices and trans- parency across the biomedical literature. PLoS Biol. 2016;14(1):e1002333.

[57] Holdren JP. Increasing access to the results of federally funded scientific research. Memorandum for the heads of executive departments and agencies. Office of Science and Technology Policy, Executive Office of the President, Washington, DC. 2013;Available from: https://www. whitehouse.gov/sites/default/files/ microsites/ostp/ostp_public_access_memo_2013. pdf.

[58] Miguel E, Camerer C, Casey K, Cohen J, Esterling KM, Gerber A, et al. Promoting transparency in social science research. Science. 2014;343(6166):30-31.

[59] Roche DG, Lanfear R, Binning SA, Haff TM, Schwanz LE, Cain KE, et al. Troubleshooting public data archiving: suggestions to increase participation. PLoS Biol. 2014;12(1):e1001779.

[60] Chalmers I, Bracken MB, Djulbegovic B, Garattini S, Grant J, Gülmezoglu AM, et al. How to increase value and reduce waste when research priorities are set. The Lancet. 2014;383(9912):156-165.

[61] Ioannidis JP, Greenland S, Hlatky MA, Khoury MJ, Macleod MR, Moher D, et al. Increasing value and reducing waste in research design, conduct, and analysis. The Lancet. 2014;383(9912):166-175.

[62] Salman RAS, Beller E, Kagan J, Hemminki E, Phillips RS, Savulescu J, et al. Increasing value and reducing waste in biomedical research regulation and management. The Lancet. 2014;383(9912):176-185.

[63] Yordanov Y, Dechartres A, Porcher R, Boutron I, Altman DG, Ravaud P. Avoidable waste of research related to inadequate methods in clinical trials. BMJ. 2015;350:h809.

[64] Moher D, Altman DG. Four proposals to help improve the medical research literature. PLoS Med. 2015;12(9):e1001864.

[65] Ioannidis JP, Khoury MJ. Assessing value in biomedical research: the PQRST of appraisal and reward. JAMA. 2014;312(5):483-484.

[66] Vasilevsky NA, Brush MH, Paddock H, Ponting L, Tripathy SJ, LaRocca GM, et al. On the reproducibility of science: unique identification of research resources in the biomedical literature. PeerJ. 2013;1:e148.

[67] International Committee of Medical Journal Editors, et al. Uniform requirements for manuscripts submitted to biomedical journals: writing and editing for biomedical publication. Haematologica. 2004;89(3):264.

[68] Kilkenny C, Browne WJ, Cuthill IC, Emerson M, Altman DG. Improving bioscience research reporting: the ARRIVE guidelines for reporting animal research. PLoS Biol. 2010;8(6):e1000412.

[69] Macleod MR, Fisher M, O'Collins V, Sena ES, Dirnagl $\mathrm{U}$, Bath PM, et al. Good laboratory practice: preventing introduction of bias at the bench. Journal of Cerebral Blood Flow \& Metabolism. 2009;29(2):221-223.

[70] Tooth L, Ware R, Bain C, Purdie DM, Dobson A. Quality of reporting of observational longitudinal research. American Journal of Epidemiology. 2005;161(3):280288.

[71] Festing MF, Altman DG. Guidelines for the design and statistical analysis of experiments using laboratory animals. ILAR Journal. 2002;43(4):244-258.

[72] Moher D, Schulz KF, Simera I, Altman DG. Guidance for developers of health research reporting guidelines. 
PLoS Med. 2010;7(2):e1000217.

[73] Casadevall A, Fang FC. Reforming science: methodological and cultural reforms. Infection and Immunity. 2012;80(3):891-896.

[74] Nosek BA, Bar-Anan Y. Scientific utopia: I. Opening scientific communication. Psychological Inquiry. 2012;23(3):217-243.

[75] Nosek BA, Spies JR, Motyl M. Scientific utopia: II. Restructuring incentives and practices to promote truth over publishability. Perspectives on Psychological Science. 2012;7(6):615-631.

[76] Everett JA, Earp BD. A tragedy of the (academic) commons: interpreting the replication crisis in psychology as a social dilemma for early-career researchers. Frontiers in Psychology. 2015;6.

[77] Nekrutenko A, Taylor J. Next-generation sequencing data interpretation: enhancing reproducibility and accessibility. Nature Reviews Genetics. 2012;13(9):667672.

[78] Sandve GK, Nekrutenko A, Taylor J, Hovig E. Ten simple rules for reproducible computational research. PLoS Comput Biol. 2013;9(10):e1003285.

[79] Ioannidis JP, Khoury MJ. Improving validation practices in "omic" research. Science. 2011;334(6060):12301232.

[80] Pusztai L, Hatzis C, Andre F. Reproducibility of research and preclinical validation: problems and solutions. Nature Reviews Clinical Oncology. 2013;10(12):720-724.

[81] Valentine JC, Biglan A, Boruch RF, Castro FG, Collins LM, Flay BR, et al. Replication in prevention science. Prevention Science. 2011;12(2):103-117.

[82] Kidwell MC, Lazarević LB, Baranski E, Hardwicke TE, Piechowski S, Falkenberg LS, et al. Badges to acknowledge open practices: a simple, low-cost, effective method for increasing transparency. PLoS Biol. 2016;14(5):e1002456.

[83] Koole SL, Lakens D. Rewarding replications: a sure and simple way to improve psychological science. Perspectives on Psychological Science. 2012;7(6):608-614.

[84] Landis SC, Amara SG, Asadullah K, Austin CP, Blumenstein R, Bradley EW, et al. A call for transparent reporting to optimize the predictive value of preclinical research. Nature. 2012;490(7419):187-191.

[85] Moher D, Hopewell S, Schulz KF, Montori V, Gøtzsche PC, Devereaux P, et al. CONSORT 2010 explanation and elaboration: updated guidelines for reporting parallel group randomised trials. Journal of Clinical Epidemiology. 2010;63(8):e1-e37.

[86] Moseley ET, Hsu DJ, Stone DJ, Celi LA. Beyond open big data: addressing unreliable research. Journal of Medical Internet Research. 2014;16(11).

[87] Peers IS, Ceuppens PR, Harbron C. In search of preclinical robustness. Nature Reviews Drug Discovery. 2012;11(10).

[88] Peers IS, South MC, Ceuppens PR, Bright JD, Pilling E. Can you trust your animal study data? Nature Reviews Drug Discovery. 2014;13(7):560-560.

[89] Ram K. Git can facilitate greater reproducibility and increased transparency in science. Source Code for Biology and Medicine. 2013;8(1):1.

[90] Schooler JW. Metascience could rescue the "replication crisis". Nature. 2014;515:9.

[91] Baker D, Lidster K, Sottomayor A, Amor S. Two years later: journals are not yet enforcing the ARRIVE guidelines on reporting standards for pre-clinical animal studies. PLoS Biol. 2014;12(1):e1001756.

[92] Vanpaemel W, Vermorgen M, Deriemaecker L, Storms G. Are we wasting a good crisis? The availability of psychological research data after the storm. Collabra. 2015;1(1). doi:10.1525/collabra.13.

[93] Roche DG, Kruuk LE, Lanfear R, Binning SA. Public data archiving in ecology and evolution: how well are we doing? PLoS Biol. 2015;13(11):e1002295.

[94] Vines TH, Albert AY, Andrew RL, Débarre F, Bock DG, Franklin MT, et al. The availability of research data declines rapidly with article age. Current Biology. 2014;24(1):94-97.

[95] Wicherts JM, Borsboom D, Kats J, Molenaar D. The poor availability of psychological research data for reanalysis. American Psychologist. 2006;61(7):726.

[96] Moher D, Glasziou P, Chalmers I, Nasser M, Bossuyt PM, Korevaar DA, et al. Increasing value and reducing waste in biomedical research: who's listening? The Lancet. 2016;387(10027):1573-1586.

[97] Grant SP, Mayo-Wilson E, Melendez-Torres G, Montgomery P. Reporting quality of social and psychological intervention trials: a systematic review of reporting guidelines and trial publications. PLoS ONE. 2013;8(5):e65442.

[98] Joseph H. The open access movement grows up: taking stock of a revolution. PLoS Biol. 2013;11(10):e1001686.

[99] Song F, Parekh S, Hooper L, Loke YK, Ryder J, Sutton AJ, et al. Dissemination and publication of research findings: an updated review of related biases. Health Technol Assess. 2010;14(8):1-193.

[100] Prayle AP, Hurley MN, Smyth AR. Compliance with mandatory reporting of clinical trial results on ClinicalTrials.gov: cross sectional study. BMJ. 2012;344:d7373.

[101] Clarke M, Hopewell S, Chalmers I. Clinical trials should begin and end with systematic reviews of relevant evidence: 12 years and waiting. The Lancet. 2010;376(9734):20-21.

[102] Flórez-Vargas O, Brass A, Karystianis G, Bramhall M, Stevens R, Cruickshank S, et al. Bias in the reporting of sex and age in biomedical research on mouse models. ELife. 2016;5:e13615.

[103] Bramhall M, Flórez-Vargas O, Stevens R, Brass A, Cruickshank S. Quality of methods reporting in animal models of colitis. Inflammatory Bowel Diseases. 2015;21(6):1248-1259.

[104] Plint AC, Moher D, Morrison A, Schulz K, Altman DG, Hill C, et al. Does the CONSORT checklist improve the quality of reports of randomised controlled trials? A systematic review. Medical Journal of Australia. 2006;185(5):263.

[105] Begley CG, Ioannidis JP. Reproducibility in science: improving the standard for basic and preclinical research. Circulation Research. 2015;116(1):116-126.

[106] Simmons JP, Nelson LD, Simonsohn U. False-positive psychology: undisclosed flexibility in data collection and analysis allows presenting anything as significant. Psychological Science. 2011;doi:10.1177/0956797611417632.

[107] Fiedler K. Voodoo correlations are everywhere - not only in neuroscience. Perspectives on Psychological Science. 2011;6(2):163-171.

[108] Ferguson CJ, Heene M. A vast graveyard of undead theories: publication bias and psychological science's aver- 
sion to the null. Perspectives on Psychological Science. 2012;7(6):555-561.

[109] Young NS, Ioannidis JP, Al-Ubaydli O. Why current publication practices may distort science. PLoS Med. 2008;5(10):e201.

[110] Tsilidis KK, Panagiotou OA, Sena ES, Aretouli E, Evangelou E, Howells DW, et al. Evaluation of excess significance bias in animal studies of neurological diseases. PLoS Biol. 2013;11(7):e1001609.

[111] Brembs B, Munafò M. Deep impact: unintended consequences of journal rank. 2013;arXiv:1301.3748.

[112] Steen RG, Casadevall A, Fang FC. Why has the number of scientific retractions increased? PLoS ONE. 2013;8(7):e68397.

[113] O'Boyle EH, Banks GC, Gonzalez-Mulé E. The Chrysalis Effect: how ugly initial results metamorphosize into beautiful articles. Journal of Management. 2014;doi:10.1177/0149206314527133.

[114] Stamatakis E, Weiler R, Ioannidis J. Undue industry influences that distort healthcare research, strategy, expenditure and practice: a review. European Journal of Clinical Investigation. 2013;43(5):469-475.

[115] Sena ES, Van Der Worp HB, Bath PM, Howells DW, Macleod MR. Publication bias in reports of animal stroke studies leads to major overstatement of efficacy. PLoS Biol. 2010;8(3):e1000344.

[116] Mathieu S, Boutron I, Moher D, Altman DG, Ravaud P. Comparison of registered and published primary outcomes in randomized controlled trials. JAMA. 2009;302(9):977-984.

[117] Hannink G, Gooszen HG, Rovers MM. Comparison of registered and published primary outcomes in randomized clinical trials of surgical interventions. Annals of Surgery. 2013;257(5):818-823.

[118] Crowe S, Fenton M, Hall M, Cowan K, Chalmers I. Patients', clinicians' and the research communities' priorities for treatment research: there is an important mismatch. Research Involvement and Engagement. 2015;1(1):1-10. doi:10.1186/s40900-015-0003-x.

[119] Blümle A, Meerpohl JJ, Schumacher M, von Elm E. Fate of clinical research studies after ethical approval follow-up of study protocols until publication. In: Ethics and Governance of Biomedical Research. Springer; 2016. p. 109-123.

[120] Chan AW, Song F, Vickers A, Jefferson T, Dickersin $\mathrm{K}$, Gøtzsche PC, et al. Increasing value and reducing waste: addressing inaccessible research. The Lancet. 2014;383(9913):257-266.

[121] Glasziou P, Altman DG, Bossuyt P, Boutron I, Clarke $\mathrm{M}$, Julious $\mathrm{S}$, et al. Reducing waste from incomplete or unusable reports of biomedical research. The Lancet. 2014;383(9913):267-276.

[122] Glasziou P. The role of open access in reducing waste in medical research. PLoS Med. 2014;11(5):e1001651.

[123] Hoffmann T, Erueti C, Thorning S, Glasziou P. The scatter of research: cross sectional comparison of randomised trials and systematic reviews across specialties. BMJ. 2012;344(3223).

[124] Franco A, Malhotra N, Simonovits G. Publication bias in the social sciences: unlocking the file drawer. Science. 2014;345(6203):1502-1505.

[125] Button KS, Ioannidis JP, Mokrysz C, Nosek BA, Flint J, Robinson ES, et al. Power failure: why small sample size undermines the reliability of neuroscience. Nature
Reviews Neuroscience. 2013;14(5):365-376.

[126] Dwan K, Altman DG, Arnaiz JA, Bloom J, Chan AW, Cronin E, et al. Systematic review of the empirical evidence of study publication bias and outcome reporting bias. PLoS ONE. 2008;3(8):e3081.

[127] Ioannidis JP. Why most discovered true associations are inflated. Epidemiology. 2008;19(5):640-648.

[128] Van der Worp HB, Howells DW, Sena ES, Porritt MJ, Rewell S, O'Collins V, et al. Can animal models of disease reliably inform human studies? PLoS Med. 2010;7(3):e1000245.

[129] Ioannidis JP. Why science is not necessarily selfcorrecting. Perspectives on Psychological Science. 2012;7(6):645-654.

[130] Stroebe W, Postmes T, Spears R. Scientific misconduct and the myth of self-correction in science. Perspectives on Psychological Science. 2012;7(6):670-688.

[131] Wagenmakers EJ, Wetzels R, Borsboom D, van der Maas HL, Kievit RA. An agenda for purely confirmatory research. Perspectives on Psychological Science. 2012;7(6):632-638.

[132] John LK, Loewenstein G, Prelec D. Measuring the prevalence of questionable research practices with incentives for truth telling. Psychological Science. 2012;doi:10.1177/0956797611430953.

[133] Fanelli D. Negative results are disappearing from most disciplines and countries. Scientometrics. 2011;90(3):891-904.

[134] Alberts B, Kirschner MW, Tilghman S, Varmus H. Rescuing US biomedical research from its systemic flaws. Proceedings of the National Academy of Sciences. 2014;111(16):5773-5777.

[135] Ioannidis JP, Munafo MR, Fusar-Poli P, Nosek BA, David SP. Publication and other reporting biases in cognitive sciences: detection, prevalence, and prevention. Trends in Cognitive Sciences. 2014;18(5):235-241.

[136] Chambers CD, Feredoes E, Muthukumaraswamy SD, Etchells P. Instead of "playing the game" it is time to change the rules: registered reports at AIMS Neuroscience and beyond. AIMS Neuroscience. 2014;1(1):417.

[137] Glasziou P, Haynes B. The paths from research to improved health outcomes. Evidence Based Nursing. $2005 ; 8(2): 36-38$.

[138] Duff JM, Leather H, Walden EO, LaPlant KD, George TJ. Adequacy of published oncology randomized controlled trials to provide therapeutic details needed for clinical application. Journal of the National Cancer Institute. 2010;102(10):702-705.

[139] Dancey JE. From quality of publication to quality of care: translating trials to practice. Journal of the National Cancer Institute. 2010;102(10):670-671.

[140] Kilkenny C, Parsons N, Kadyszewski E, Festing MF, Cuthill IC, Fry D, et al. Survey of the quality of experimental design, statistical analysis and reporting of research using animals. PLoS ONE. 2009;4(11):e7824.

[141] McGlynn EA, Asch SM, Adams J, Keesey J, Hicks J, DeCristofaro A, et al. The quality of health care delivered to adults in the United States. New England Journal of Medicine. 2003;348(26):2635-2645.

[142] Lemon R, Dunnett SB. Surveying the literature from animal experiments. BMJ. 2005;330(7498):977-978.

[143] Ioannidis JP, Lau J. Completeness of safety reporting in randomized trials: an evaluation of 7 medical areas. 
JAMA. 2001;285(4):437-443.

[144] Savović J, Jones HE, Altman DG, Harris RJ, Jüni P, Pildal J, et al. Influence of reported study design characteristics on intervention effect estimates from randomized, controlled trials. Annals of Internal Medicine. 2012;157(6):429-438.

[145] Turner EH, Matthews AM, Linardatos E, Tell RA, Rosenthal R. Selective publication of antidepressant trials and its influence on apparent efficacy. New England Journal of Medicine. 2008;358(3):252-260.

[146] Bero LA, Grilli R, Grimshaw JM, Harvey E, Oxman AD, Thomson MA. Closing the gap between research and practice: an overview of systematic reviews of interventions to promote the implementation of research findings. BMJ. 1998;317(7156):465-469.

[147] Ramagopalan S, Skingsley AP, Handunnetthi L, Klingel M, Magnus D, Pakpoor J, et al. Prevalence of primary outcome changes in clinical trials registered on ClinicalTrials.gov: a cross-sectional study. F1000Research. 2014;3(77). doi:10.12688/f1000research.3784.1.

[148] Williamson P, Altman D, Blazeby J, Clarke M, Gargon E. Driving up the quality and relevance of research through the use of agreed core outcomes. Journal of Health Services Research \& Policy. 2012;17(1):1-2.

[149] Stephan PE. The economics of science. Journal of Economic Literature. 1996;34(3):1199-1235.

[150] Knuteson B. Blunt honesty, incentives, and knowledge exchange. 2016; arXiv:1602.06188.

[151] Lykken DT. Statistical significance in psychological research. Psychological Bulletin. 1968;70(3p1):151.

[152] Elms AC. The crisis of confidence in social psychology. American Psychologist. 1975;30(10):967.

[153] Greenwald AG. Consequences of prejudice against the null hypothesis. Psychological Bulletin. 1975;82(1):1.

[154] Rosenthal R. The file drawer problem and tolerance for null results. Psychological Bulletin. 1979;86(3):638.

[155] Altman DG. The scandal of poor medical research. BMJ. 1994;308(6924):283-284.

[156] Hackam DG, Redelmeier DA. Translation of research evidence from animals to humans. JAMA. 2006;296(14):1727-1732.

[157] Pocock SJ, Hughes MD, Lee RJ. Statistical problems in the reporting of clinical trials. New England Journal of Medicine. 1987;317(7):426-432.

[158] Sterling TD, Rosenbaum WL, Weinkam JJ. Publication decisions revisited: the effect of the outcome of statistical tests on the decision to publish and vice versa. The American Statistician. 1995;49(1):108-112.

[159] Vul E, Harris C, Winkielman P, Pashler H. Puzzlingly high correlations in fMRI studies of emotion, personality, and social cognition. Perspectives on Psychological Science. 2009;4(3):274-290.

[160] Easterbrook PJ, Gopalan R, Berlin J, Matthews DR. Publication bias in clinical research. The Lancet. 1991;337(8746):867-872.

[161] Kerr NL. HARKing: hypothesizing after the results are known. Personality and Social Psychology Review.
1998;2(3):196-217.

[162] Knuteson B. Capitalist science. 2011;arXiv:1102.2474.

[163] Open science, or even-more-socialist science, is a common theme among proposed incremental improvements. The idea of encouraging more transparent access to data and analysis code is an attractive one. We ourselves pushed it in particle physics - hard, and for many years. Unfortunately, if unsurprisingly, incentives are simply too misaligned for it to work. If we, as a society, want more of something - like apples, say, or knowledge about how nature works - we may be better off making it easy for people who produce apples to sell them than mandating that they make their orchards available for anyone to pick.

[164] The phrase "socialist science" is obviously a grotesquely crude caricature of the intricate and often nuanced set of incentives joining the actors in the current science ecosystem. We intend the phrase as a neutral description of an aspect of the current ecosystem germane to the present discussion. A reader who dislikes the phrase is encouraged to mentally replace it with "the ecosystem within which science is currently carried out," or some alternative reference thereto.

[165] We focus on the incentive flaws common to all socialist science, ignoring differences among scientific disciplines. Rather than treat the symptoms, which express differently in the social sciences, life sciences, and physical sciences, we focus on the underlying disease.

[166] Kn-X; http://kn-x.com. Patent pending.

[167] The phrase "capitalist science" is intended as a neutral description of a salient feature of this new ecosystem. A reader who dislikes the phrase is encouraged to mentally replace it with "the new ecosystem," or something similar.

[168] The "capitalist science" in this article supersedes that of Ref. [162], which in retrospect is more of a hybrid between socialist and capitalist science.

[169] To be clear, our use of the term "capitalist" does not arise from a belief, seemingly held by many, that free markets are the optimal solution to all problems, nor from a belief that global financial markets at the time of this writing function well and should be emulated. (You have no idea.) The complexity and frequent opacity of today's capitalism highlights the glaring need for a mechanism facilitating useful, bluntly honest information transfer between remote parties. Given the embarrassing, hidden-in-plain-sight, farcically tragic comedy of errors that is recent financial history, a mechanism facilitating useful, bluntly honest, arm's length information transfer may turn out to be our best shot at saving capitalism ... or at least at sending a few of those responsible to prison next time around.

[170] Although the information market unleashed by capitalist science could create millions of new science-related jobs, it would be irresponsible to reduce funding to socialist science until that promise has been realized. 